\title{
A COMPARATIVE ANALYSIS OF ADVERTISEMENT CONTENTS OF SELECT FMCG PRODUCTS OF INDIA AND WESTERN COUNTRIES
}

\author{
Dr. Kushal De \\ Assistant Professor of Commerce, \\ Dhruba Chand Halder College \\ Dakshin Barasat, \\ West Bengal, \\ India
}

\author{
Nandini Mitra \\ Guest Lecturer, \\ Surendranath College, \\ Kolkata, \\ West Bengal, \\ India
}

Article DOI: https://doi.org/10.36713/epra4684

\begin{abstract}
Advertisement is the best medium for any business to attract, educate and stimulate its potential customer and thereby, push through actual sales.In today`s world, advertisement not only creates demands for the product but also successfully creates needs and attracts the customer towards created needs. A successful and creative advertisement not only establishes the product but it also establishes the brand for its future success. Survival in a competitive market depends on the level of trust, confidence and loyalty of customers which are usually created and sustained through advertisements. The challenge is huge for MNCs as they have to adjust their message, contents, features and timing according to the land, its culture, its beliefs, its likings and disliking, its taste and preferences and so on.The present study makes a comparative analysis of the advertisement contents of FMCG products between India and Western countries. From the research, it is clearly found that the contents, visuals and messages are planned and designed to cater socio cultural demands of target population. The advertisements emphasize on core product features in both places in general but there are subtle differences in content of messages.
\end{abstract}

KEYWORDS: advertisement, customer, brand, culture, preference, interest.

\section{INTRODUCTION}

The term advertisement impliespromotion of a product, brand or service to viewers in order to attract interest, engagement and sales. It is an ancient practice and has been carried out since time immemorial.Printed advertising in English magazines dates back to the $17^{\text {th }}$ century. In America, the first newspaper advertisements were placed in the early $18^{\text {th }}$ century. The first advertising agency was set up in the United States in 1841.

Advertisement is created on the basis culture, beliefs, perceptions and interest of people who are being targeted.It has to be admitted that most consumers take their decisions based on emotions, not logic or reasons. They also react differently and derive different conclusion under similar circumstances. Advertisers thus have tried to read the pulse of their targets and today, in a knowledge economy, they have become demand creators.
Indian economy, since liberalization has grown at steady rate and has been preferred destination of many MNCs. Indian firms are also going global and making remarkable presence in world markets. Indian economy and the West have maintained their boom since the last two decades and similar trends are expected to continue. Several products which were not available in Indian markets previously are readily available today. Indian consumers with increased per capita income have been focal point of many global concerns.

Advertisement is the best medium for any business to attract, educate and stimulate its potential customer and thereby, push through actual sales. People view the product through advertisement and after perceptual need satisfaction they plan to use the product. In today's world, advertisement not only creates demands for the product but also successfully creates needs and attracts the customer towards created needs. A successful and creative advertisement not only establishes the product but it 
also establishes the brand for its future success. Survival in a competitive market depends on the level of trust, confidence and loyalty of customers which are usually created and sustained through advertisements. Customers are also conscious about the product quality and are more informed than ever before due to availability of all requisite information in the internet.

Advertisement today is an art to successfully establish and maintain customer loyalty. The challenge is huge for MNCs as they have to adjust their message, contents, features and timing according to the land, its culture, its beliefs, its likings and disliking, its taste and preferences and so on. This herculean task is successfully negotiated by many firms globally. They adjust to local demands besides maintaining their global image. The secret of success usually lays in the situation appropriate advertisements that they display.

Under the above backdrop, the present study makes a comparative analysis of the advertisement contents of FMCG products between India and Western countries. Advertisements of popular products sold in India and also in the West are selected and studied.

\section{DATA AND METHODOLOGY}

For the purpose of this study, advertisements of FMCG products were considered which are featured in Indian media as well as in West. Advertisements of similar products were taken up and the message and contents were thoroughly analyzed. The similarities and differences projected for the same product in two different cultural setups were noted. The subtle differences in projections to adjust to a particular culture were also taken note of. The assessments such made were then tabulated with similar products being clubbed into distinct segments, presented and meaningful inferences were drawn.

\section{FINDINGS FROM THE STUDY:}

\begin{tabular}{|c|c|c|c|}
\hline $\begin{array}{c}\text { Sl } \\
\text { No }\end{array}$ & $\begin{array}{l}\text { Product Name and Content } \\
\text { of the Advertisement }\end{array}$ & Indian Advertisement & $\begin{array}{l}\text { Advertisement in Western } \\
\text { Countries }\end{array}$ \\
\hline 1 & $\begin{array}{l}\text { Coca-cola } \\
\text { India- The product focus on } \\
\text { entertainment with friends. } \\
\text { USA- The product gives a } \\
\text { message to unite all. }\end{array}$ & $\begin{array}{l}\text { It shows four young girls } \\
\text { taking a drink break at the } \\
\text { same time and notice that their } \\
\text { favorite hero is also enjoying } \\
\text { his. So with Coca-Cola it will } \\
\text { turn up your times. }\end{array}$ & $\begin{array}{l}\text { It shows a beautiful girl } \\
\text { sharing Coke with friends } \\
\text { with joy and happiness and } \\
\text { she spread the message } \\
\text { among society. }\end{array}$ \\
\hline 2 & $\begin{array}{l}7 \text { Up } \\
\text { India- The product shows } \\
\text { how } 7 \text { Up and Fido Dido } \\
\text { opens frontal cortex. } \\
\text { USA- The product shows } \\
\text { winning the customer minds. }\end{array}$ & $\begin{array}{l}\text { It shows couples in a beach } \\
\text { suddenly notice a familiar face } \\
\text { at the beach - an uncle from his } \\
\text { neighbourhood. A } 7 \text { Up drink } \\
\text { and its Fido Dido rescue the } \\
\text { couple with ideas. }\end{array}$ & $\begin{array}{l}\text { It shows finding and winning } \\
\text { the customer through } \\
\text { generating emphasizes on } \\
\text { needs for the product. }\end{array}$ \\
\hline 3 & $\begin{array}{l}\text { Pepsi. } \\
\text { India-Pepsi is irrestible in } \\
\text { any situation. } \\
\text { USA- In any time and any } \\
\text { place Pepsi for all generation. }\end{array}$ & $\begin{array}{l}\text { It shows a group of college } \\
\text { students are on hunger strike } \\
\text { against new rules of their } \\
\text { administration but one young } \\
\text { boy can't resist the Pepsi in } \\
\text { this difficult condition. }\end{array}$ & $\begin{array}{l}\text { It shows people getting a } \\
\text { glimpse of some Pepsi cans } \\
\text { on the Moon and on Mars and } \\
\text { every generation celebrating } \\
\text { this product. }\end{array}$ \\
\hline 4 & $\begin{array}{l}\text { Mountain-Dew } \\
\text { India - The product focus on } \\
\text { for achieving goals by } \\
\text { overcome the fear. } \\
\text { USA- The product shows } \\
\text { achieving goals in any } \\
\text { circumstances. }\end{array}$ & $\begin{array}{l}\text { It shows the spirit of those who } \\
\text { push themselves in the face of } \\
\text { fear to achieve extraordinary } \\
\text { results. }\end{array}$ & $\begin{array}{l}\text { It shows nothing can stop } \\
\text { you if you have willingness to } \\
\text { do it. As the person entering } \\
\text { the car through window } \\
\text { though having difficulties to } \\
\text { do so. }\end{array}$ \\
\hline 5 & $\begin{array}{l}\text { Sprite } \\
\text { India- the product focuses } \\
\text { on summer refreshment. } \\
\text { USA-The product shows in } \\
\text { summer with under pressure } \\
\text { to stay in a refresh mind. }\end{array}$ & $\begin{array}{l}\text { Two friends are restless and } \\
\text { fed-up with the heat. They } \\
\text { reach an AC theatere to find it } \\
\text { house full. Then the other boy } \\
\text { takes a swig on his sprite and } \\
\text { he freshens up his mind. }\end{array}$ & $\begin{array}{l}\text { It shows in a base ball match } \\
\text { the players earn Sprite by } \\
\text { winning and the audience are } \\
\text { also enjoying the Sprite at the } \\
\text { end of the game. }\end{array}$ \\
\hline
\end{tabular}




\begin{tabular}{|c|c|c|c|}
\hline 6 & $\begin{array}{l}\text { Tropicana } \\
\text { India-The product focus on } \\
\text { iron power for health. } \\
\text { USA-The product focus on } \\
\text { power of probiotics with fruit } \\
\text { juice. }\end{array}$ & $\begin{array}{l}\text { It shows a beautiful lady doing } \\
\text { exercise with iron for a healthy } \\
\text { body but it is not enough as } \\
\text { she need iron and vitamin } \\
\text { which is present in Tropicana. }\end{array}$ & $\begin{array}{l}\text { It shows probiotic delicious } \\
\text { hundred percent fruit juice } \\
\text { with peel grain that feel } \\
\text { great. }\end{array}$ \\
\hline 7 & $\begin{array}{l}\text { Maggi } \\
\text { India- It shows Maggi can be } \\
\text { cooked easily and accepted } \\
\text { by all ages. } \\
\text { South Africa- The product } \\
\text { focus on quick food with high } \\
\text { nutrition. }\end{array}$ & $\begin{array}{l}\text { It shows that Maggi can be } \\
\text { cooked well by young women } \\
\text { willing to be independent and } \\
\text { staying single. The easy recipee } \\
\text { is followed by generations. }\end{array}$ & $\begin{array}{l}\text { It shows how people proudly } \\
\text { choose Maggi and they } \\
\text { believe it is a smartest choice } \\
\text { with high source of food } \\
\text { nutrition. }\end{array}$ \\
\hline 8 & $\begin{array}{l}\text { Top Ramen } \\
\text { India- The product shows } \\
\text { people can have the old } \\
\text { happiness again with same } \\
\text { taste and confidence. } \\
\text { UK- The product focus on } \\
\text { everybody chooses a new } \\
\text { option. }\end{array}$ & $\begin{array}{l}\text { It shows that two brothers } \\
\text { were bored due to common } \\
\text { food with bread and jam. } \\
\text { Suddenly they notice their } \\
\text { mother has brought Top } \\
\text { Ramen which was again sold in } \\
\text { the market and they were very } \\
\text { happy to have it again. }\end{array}$ & $\begin{array}{l}\text { It shows a new way and } \\
\text { quick option for the healthy } \\
\text { food with a great taste with } \\
\text { all, knowing re-utilization of } \\
\text { basic minerals like salt. }\end{array}$ \\
\hline 9 & $\begin{array}{l}\text { Nescafe } \\
\text { India- The product focus on } \\
\text { an emotional moment of life } \\
\text { with responsibility. } \\
\text { UK- The product shows an } \\
\text { emotional feelings and } \\
\text { focuses importantance of } \\
\text { spending time with those } \\
\text { who cares about him. }\end{array}$ & $\begin{array}{l}\text { It delivers a strong and } \\
\text { responsible message through } \\
\text { father to son at very early } \\
\text { morning for being selected at } \\
\text { fathers college for higher } \\
\text { studies. }\end{array}$ & $\begin{array}{l}\text { It Shows one person bringing } \\
\text { all his acquitances and } \\
\text { systematically reducing the } \\
\text { numbers to finally have } \\
\text { coffee with only those who } \\
\text { know him well. This } \\
\text { rekindles the lost touch. }\end{array}$ \\
\hline 10 & $\begin{array}{l}\text { Tetley } \\
\text { India - It shows one of the } \\
\text { bigest challangees of our } \\
\text { daily lifestyle. } \\
\text { UK - It shows togetherness } \\
\text { feelings. }\end{array}$ & $\begin{array}{l}\text { It shows in today's world with } \\
\text { friends and family it is very } \\
\text { difficult to maintain daily } \\
\text { healthy food without oil and } \\
\text { fat. So one can have Tetley } \\
\text { green tea everyday as it has } \\
\text { five times more antioxident } \\
\text { than apple. }\end{array}$ & $\begin{array}{l}\text { It shows in a rainy day a cat } \\
\text { and a dog enjoying and } \\
\text { chatting as tetley tea can } \\
\text { makes anyone to talks their } \\
\text { feeling with each other }\end{array}$ \\
\hline 11 & $\begin{array}{l}\text { Lipton } \\
\text { India- The product focus on } \\
\text { keep healthy. } \\
\text { USA- Product show natural } \\
\text { freshness added in life. }\end{array}$ & $\begin{array}{l}\text { It shows exercise with green } \\
\text { tea keeps everybody healthy } \\
\text { for long as its reduces fat and } \\
\text { increases metabolism. }\end{array}$ & $\begin{array}{l}\text { It shows a beautiful tea } \\
\text { garden with the help of the } \\
\text { pure nature how sunshine } \\
\text { and rain help the tea to grow } \\
\text { leaf nutritious healthy. }\end{array}$ \\
\hline 12 & $\begin{array}{l}\text { Colgate } \\
\text { India-It shows on smile and } \\
\text { get started. } \\
\text { USA- It shows for every } \\
\text { mouth protection of colgate } \\
\text { is essential. }\end{array}$ & $\begin{array}{l}\text { It shows a couple adopting a } \\
\text { child and makes her feel like a } \\
\text { family member with a smile, } \\
\text { which is symbolic of hope and } \\
\text { optimism. }\end{array}$ & $\begin{array}{l}\text { It shows we need anti } \\
\text { bacterial protection for } \\
\text { healthier mouth. }\end{array}$ \\
\hline 13 & $\begin{array}{l}\text { Oral-B } \\
\text { India- Product shows one } \\
\text { solution for many problems. } \\
\text { UK- Product stress on clean } \\
\text { and healthy teeth. }\end{array}$ & $\begin{array}{l}\text { The toothpaste having eight } \\
\text { different advantages fulfils } \\
\text { types of need for teeth. It is the } \\
\text { only solution. }\end{array}$ & $\begin{array}{l}\text { It shows for a healthier } \\
\text { mouth with cleaner teeth and } \\
\text { the product is recommended } \\
\text { by doctors. }\end{array}$ \\
\hline
\end{tabular}




\begin{tabular}{|c|c|c|c|}
\hline 14 & $\begin{array}{l}\text { Sensodyne } \\
\text { India- It focus dual } \\
\text { advantage of the product. } \\
\text { UK- It focus on stronger and } \\
\text { repaired teeth }\end{array}$ & $\begin{array}{l}\text { It shows benefit in sensitive } \\
\text { teeth and helps bringing back } \\
\text { the natural whiteness of teeth } \\
\text { on daily usage. }\end{array}$ & $\begin{array}{l}\text { It describe a sensitive teeth } \\
\text { can be repaired. It provides } \\
\text { long lasting protection for } \\
\text { coating sensitive teeth which } \\
\text { is recommended by doctor. }\end{array}$ \\
\hline 15 & $\begin{array}{l}\text { Loreal } \\
\text { India-The product is one } \\
\text { solution for five problems } \\
\text { USA-The product focus on } \\
\text { colour protection of the hair. }\end{array}$ & $\begin{array}{l}\text { It shows this product fights the } \\
\text { five signs of damaged hair } \\
\text { dryness,roughness,dullness fall } \\
\text { and split ends with conditioner } \\
\text { in its become all in one. }\end{array}$ & $\begin{array}{l}\text { It shows how shampoo with } \\
\text { no sulphates and no foam } \\
\text { cleanse and condition for } \\
\text { every type of hair. }\end{array}$ \\
\hline 16 & $\begin{array}{l}\text { Pantene } \\
\text { India- The product focus on } \\
\text { freedom of hair. } \\
\text { UK- The product focus on } \\
\text { strong is beautiful. }\end{array}$ & $\begin{array}{l}\text { It shows open hair adds a new } \\
\text { dimension to your personality. } \\
\text { It has pro-v so it build up of } \\
\text { your personality with less hair } \\
\text { fall. }\end{array}$ & $\begin{array}{l}\text { It shows the hair strength of } \\
\text { a beautiful woman. It has } \\
\text { multinutrient, pro-v blend } \\
\text { and antioxident lipids that } \\
\text { makes hair much stronger. }\end{array}$ \\
\hline 17 & $\begin{array}{l}\text { Head and Shoulders } \\
\text { India- The product focus on } \\
\text { confidence of a woman. } \\
\text { UK- The product focus on } \\
\text { nourishing care of hair. }\end{array}$ & $\begin{array}{l}\text { It shows a beautiful lady hide } \\
\text { her hair having dandruff from } \\
\text { others. After using the product, } \\
\text { she is dandruff free and she } \\
\text { regain her confidence. }\end{array}$ & $\begin{array}{l}\text { It shows the product uses } \\
\text { lavender to give shiny, } \\
\text { glossy, break free and } \\
\text { dandruf free hair which all } \\
\text { women admire. }\end{array}$ \\
\hline 18 & $\begin{array}{l}\text { Dove (Shampoo) } \\
\text { India- The product shows } \\
\text { unbeatable damage repair of } \\
\text { hair. } \\
\text { Canada- The product focus } \\
\text { on fight back against daily } \\
\text { hair damage. }\end{array}$ & $\begin{array}{l}\text { It shows splitten hair and } \\
\text { damage hair affects your } \\
\text { personality. After using the } \\
\text { product the split ends are } \\
\text { controlled and so one can } \\
\text { flaunt her hair. }\end{array}$ & $\begin{array}{l}\text { It shows through experiment } \\
\text { on flowers, how Dove } \\
\text { protects hair and resist } \\
\text { damage from heat. }\end{array}$ \\
\hline 19 & $\begin{array}{l}\text { TRESemme } \\
\text { India- The product focus on } \\
\text { get salon at home. } \\
\text { UK- The product focus on } \\
\text { natural ingredients to make } \\
\text { healthy and shiny hair. }\end{array}$ & $\begin{array}{l}\text { It shows one can make others } \\
\text { feel and recognize her } \\
\text { presense by displaying smooth } \\
\text { and beautiful hair nourished } \\
\text { by argan oil and keratin. }\end{array}$ & $\begin{array}{l}\text { A hair designer uses the } \\
\text { product to make hair reflect } \\
\text { natural beauty as it has aloe } \\
\text { vera and coconut oil and } \\
\text { devoid of silicon and dyes. }\end{array}$ \\
\hline 20 & $\begin{array}{l}\text { Dove (Soap) } \\
\text { India- The product shows } \\
\text { soft and glossy skin with } \\
\text { moisturizer. } \\
\text { Canada- The product focus } \\
\text { on keep your face feeling soft, } \\
\text { clean and nourished. }\end{array}$ & $\begin{array}{l}\text { It shows a woman uses Dove } \\
\text { with } 1 / 4 \text { th moisturizer to make } \\
\text { her skin softer and smoother } \\
\text { like a child. The effect is visible } \\
\text { in seven days. }\end{array}$ & $\begin{array}{l}\text { A woman iron worker has } \\
\text { dirt on her face and daily } \\
\text { after returning home she } \\
\text { uses Dove and it has } 1 / 4 \text { th } \\
\text { moisturizing creme to retain } \\
\text { her natural beauty so that } \\
\text { she can dress up during the } \\
\text { weekends. }\end{array}$ \\
\hline 21 & $\begin{array}{l}\text { Dettol (Soap) } \\
\text { India- The advertisement } \\
\text { shows even kids use Dettol } \\
\text { between fun or food. France- } \\
\text { The advertisement focus on } \\
\text { automatic sanitizer } \\
\text { dispenser. }\end{array}$ & $\begin{array}{l}\text { It shows in a school kids using } \\
\text { Dettol hand sanitizer to fight } \\
\text { with germs and then come } \\
\text { together to share tiffin with } \\
\text { friends. }\end{array}$ & $\begin{array}{l}\text { It shows after daily works } \\
\text { using Dettol automatic } \\
\text { sanitizer dispenser remove } \\
\text { all the germs from hand. }\end{array}$ \\
\hline 22 & $\begin{array}{l}\text { Nivea Body lotion } \\
\text { India-The product focus on } \\
\text { hydrate the skin with aloe- } \\
\text { vera. } \\
\text { USA-The product focus on } \\
\text { noticeably smoother skin. }\end{array}$ & $\begin{array}{l}\text { It shows in summer the skin } \\
\text { needs to maintain hydration. } \\
\text { The product having aloe-vera } \\
\text { extracts is ideal for summers. }\end{array}$ & $\begin{array}{l}\text { It shows this product have } \\
\text { essentially enriched body } \\
\text { lotion with unique formula of } \\
\text { nurishing almond oil which } \\
\text { moisturise the skin for } \\
\text { twenty four hours to give } \\
\text { smoothness. }\end{array}$ \\
\hline 23 & Vaseline Body lotion & It shows the product has deep & It shows our dry skin needs \\
\hline
\end{tabular}




\begin{tabular}{|c|c|c|c|}
\hline & $\begin{array}{l}\text { India-The product focus skin } \\
\text { glow. } \\
\text { UK-The product focus on } \\
\text { intensive care of skin beauty. }\end{array}$ & $\begin{array}{l}\text { restore micro droplet that } \\
\text { heals dry skin by moisturising } \\
\text { and we can do a scratch test to } \\
\text { prove the healing power. }\end{array}$ & $\begin{array}{l}\text { nutrition to protect from } \\
\text { dryness and thus the product } \\
\text { have microdroplet vaseline } \\
\text { jelly that can protect upto } \\
\text { three weeks which is proven } \\
\text { by clinics. }\end{array}$ \\
\hline 24 & $\begin{array}{l}\text { Ponds Face Wash } \\
\text { India-The product helps to } \\
\text { transform a man`s face. } \\
\text { USA-The product can control } \\
\text { men`s oily skin. }\end{array}$ & $\begin{array}{l}\text { The product having coffee bean } \\
\text { extracts that transform dull } \\
\text { face into bright one and } \\
\text { remove tiredness of the face. }\end{array}$ & $\begin{array}{l}\text { The advertisement shows } \\
\text { that by using this oil cleanser } \\
\text { a man can have protection } \\
\text { from oily skin by long lasting } \\
\text { oil control process. So don`t } \\
\text { let oily skin steal the show. }\end{array}$ \\
\hline 25 & $\begin{array}{l}\text { Horlicks } \\
\text { India-The product focus on } \\
\text { the kids hunger for growth. } \\
\text { UK-The product focus on } \\
\text { family health. }\end{array}$ & $\begin{array}{l}\text { It shows a dancer, a tennis } \\
\text { player, a junior mathematician } \\
\text { and a footballer having the } \\
\text { product to grow taller, } \\
\text { stronger and sharper as it has } \\
\text { bio available nutrients. }\end{array}$ & $\begin{array}{l}\text { It shows a family enjoying } \\
\text { christmas together and } \\
\text { having the product as a } \\
\text { healthy drink for complete } \\
\text { nourishment of all members. }\end{array}$ \\
\hline 26 & $\begin{array}{l}\text { Pediasure } \\
\text { India-The product focus on } \\
\text { better immunity and physical } \\
\text { growth. } \\
\text { USA-The product focus on } \\
\text { nutrition to help kids grow. }\end{array}$ & $\begin{array}{l}\text { The product having thirty } \\
\text { seven vital nutrients increase } \\
\text { immunity and shows visible } \\
\text { signs of growth to kids even } \\
\text { during season change. }\end{array}$ & $\begin{array}{l}\text { The product provides seven } \\
\text { grams of protein, DHA, and } \\
\text { twenty five vitamins and } \\
\text { minerals which is help to kids } \\
\text { grow faster. }\end{array}$ \\
\hline 27 & $\begin{array}{l}\text { Milo } \\
\text { India- The product focus on } \\
\text { child growth requirements. } \\
\text { Australia-The product focus } \\
\text { on child growth needs. }\end{array}$ & $\begin{array}{l}\text { The product helps kids to grow } \\
\text { as it has milk, promalt, vitamin } \\
\text { and calcium to give energy to } \\
\text { play, study and be responsible. }\end{array}$ & $\begin{array}{l}\text { It shows Victoria take care of } \\
\text { her child with this product } \\
\text { given with milk as the } \\
\text { product has more calcium, } \\
\text { more iron, more protein, } \\
\text { more vitamin for daily } \\
\text { growth. }\end{array}$ \\
\hline 28 & $\begin{array}{l}\text { Boost } \\
\text { India-The product helps kids } \\
\text { grow and compete } \\
\text { USA-The product use can } \\
\text { overcome inhibition of age }\end{array}$ & $\begin{array}{l}\text { A young cricketer was } \\
\text { underestimated by others due } \\
\text { to his tender age. He competes } \\
\text { effectively as he uses the } \\
\text { product to gain protein and } \\
\text { nutrition that increase stamina } \\
\text { three times more than others. }\end{array}$ & $\begin{array}{l}\text { It shows an aged woman } \\
\text { photographer is healthy and } \\
\text { happy and doesn`t care about } \\
\text { age as she takes the product } \\
\text { with thirty three percent } \\
\text { more protein, twenty six } \\
\text { essential vitamins like } \\
\text { calcium and others daily. }\end{array}$ \\
\hline 29 & $\begin{array}{l}\text { DairyMilk } \\
\text { India-The product focus on } \\
\text { goodness celebrated with } \\
\text { sweets } \\
\text { UK-The product focus on the } \\
\text { love in society. }\end{array}$ & $\begin{array}{l}\text { An elder brother out of } \\
\text { goodness of his heart, gives up } \\
\text { his chocolate in favour of his } \\
\text { younger brother making him } \\
\text { and their mother happy. }\end{array}$ & $\begin{array}{l}\text { A baby girl finding her } \\
\text { mother busy on phone goes } \\
\text { inside a chocolate shop, buys } \\
\text { Dairy Milk for her mother } \\
\text { and offers her precious toys } \\
\text { to the shopkeeper as she had } \\
\text { no cash. Seeing her } \\
\text { compassion, shop owner } \\
\text { gives her the product free of } \\
\text { cost. }\end{array}$ \\
\hline 30 & $\begin{array}{l}\text { Kitkat } \\
\text { India-The product shows } \\
\text { breaks are meant to be free. } \\
\text { USA-The product shows } \\
\text { happiness in every situation. }\end{array}$ & $\begin{array}{l}\text { It shows two independent } \\
\text { woman free from their work } \\
\text { pressure during break, express } \\
\text { their happiness by having and } \\
\text { sharing the product. }\end{array}$ & $\begin{array}{l}\text { It shows a woman trying to } \\
\text { do pumpkin carving and } \\
\text { failing but the pumpkin } \\
\text { wisely tells the lady not to } \\
\text { loose heart and be happy } \\
\text { with Kitkat }\end{array}$ \\
\hline 31 & Oreo & It shows a lady desirous of & Multi cultural people develop \\
\hline
\end{tabular}




\begin{tabular}{|c|c|c|c|}
\hline & $\begin{array}{l}\text { India- The product shows } \\
\text { crunchy surprise for all. } \\
\text { UK-The product focus on } \\
\text { bonding between people. }\end{array}$ & $\begin{array}{l}\text { signing on plastered hand of } \\
\text { her friend in a hospital is } \\
\text { shoked and fooled by crunchy } \\
\text { sound made from Oreo } \\
\text { biscuits. }\end{array}$ & $\begin{array}{l}\text { deep bonds among } \\
\text { themselves just like Oreo for } \\
\text { healthy relationship and } \\
\text { good taste. }\end{array}$ \\
\hline 32 & $\begin{array}{l}\text { Snickers } \\
\text { India- The product focus on } \\
\text { hunger can change the entire } \\
\text { personality. } \\
\text { UK-The product focus on } \\
\text { hunger can stop important } \\
\text { jobs. }\end{array}$ & $\begin{array}{l}\text { It shows due to hungerness a } \\
\text { responsible cricketer turns } \\
\text { into a dramatic character and } \\
\text { then his team mates give him } \\
\text { the product which in full of } \\
\text { protein,callories and nuts and } \\
\text { bring him back to his real } \\
\text { character. }\end{array}$ & $\begin{array}{l}\text { It shows in a movie hall a } \\
\text { man transforms into a } \\
\text { complaining lady but his } \\
\text { friends gives him the product } \\
\text { to end his hunger and bring } \\
\text { him back to his real } \\
\text { character. }\end{array}$ \\
\hline 33 & $\begin{array}{l}\text { Doritos } \\
\text { India- The product shows a } \\
\text { new taste for nacho chips has } \\
\text { entered in the market. } \\
\text { UK-The product focus on } \\
\text { even an unborn can be bold } \\
\text { because of it. }\end{array}$ & $\begin{array}{l}\text { It shows nacho chip with } \\
\text { golden yellow corn and cremy } \\
\text { cheese brings out the bold } \\
\text { personality hidden inside } \\
\text { everyone. }\end{array}$ & $\begin{array}{l}\text { A husband eating Doritos } \\
\text { during ultra sound of his } \\
\text { pregnant wife discovers that } \\
\text { the unborn baby is following } \\
\text { him eating the product. As } \\
\text { the product says do the bold } \\
\text { for everyone. }\end{array}$ \\
\hline 34 & $\begin{array}{l}\text { Lays } \\
\text { India- The product focus on } \\
\text { sharing smile USA- The } \\
\text { product shows operation } \\
\text { smile by contributing on } \\
\text { donation. }\end{array}$ & $\begin{array}{l}\text { It shows that a smile comes in } \\
\text { a variety of flavours and goes } \\
\text { beyond boundaries to establish } \\
\text { connection with various moods } \\
\text { and emotions. }\end{array}$ & $\begin{array}{l}\text { It shows every flavour of the } \\
\text { product spread smile and } \\
\text { happiness in every situation } \\
\text { and moment. Donation of a } \\
\text { part of profit is also shown. }\end{array}$ \\
\hline 35 & $\begin{array}{l}\text { Rexona (BodySpray) } \\
\text { India-The product focus fear } \\
\text { sue to odour } \\
\text { Australia- The product } \\
\text { shows protection in extreme } \\
\text { situation }\end{array}$ & $\begin{array}{l}\text { It shows how people reacts if } \\
\text { one has body odour even } \\
\text { though the person is well } \\
\text { dressed. The product having } \\
\text { ten times odour protection } \\
\text { saves the user from bacteria } \\
\text { caused by sweat. }\end{array}$ & $\begin{array}{l}\text { It shows three times stronger } \\
\text { protection against heat to } \\
\text { combat and fight with sweat } \\
\text { and odour while exercising. }\end{array}$ \\
\hline 36 & $\begin{array}{l}\text { Axe(BodySpray) } \\
\text { India-The product focus on } \\
\text { smell fresh and stay ready for } \\
\text { every situation. } \\
\text { UK- The product shows } \\
\text { grooming for what you are. }\end{array}$ & $\begin{array}{l}\text { It shows only couples can enter } \\
\text { a night club and a man comes } \\
\text { alone and he simply ask the } \\
\text { lady gate keeper if she can be } \\
\text { with him. As the man uses the } \\
\text { product which makes him } \\
\text { smell fresh, the lady agrees }\end{array}$ & $\begin{array}{l}\text { It shows that men don't need } \\
\text { to have six packs or costly } \\
\text { suits by simply using the } \\
\text { product they can groom } \\
\text { themselves. }\end{array}$ \\
\hline 37 & $\begin{array}{l}\text { Kellogg`s } \\
\text { India- The product shows } \\
\text { how to manage the time with } \\
\text { productivity. } \\
\text { Australia- The product } \\
\text { shows healthy family } \\
\text { relationships. }\end{array}$ & $\begin{array}{l}\text { A father grooms his daughter } \\
\text { before exams and makes her } \\
\text { have the product having } \\
\text { sufficient iron for good } \\
\text { memory and strength and } \\
\text { which lasts for three hours. }\end{array}$ & $\begin{array}{l}\text { A mother is happy as healthy } \\
\text { breakfast for her kids also } \\
\text { brings an atmosphere of } \\
\text { sharing. }\end{array}$ \\
\hline 38 & $\begin{array}{l}\text { Kellogg`s Special K } \\
\text { India-The product focus on } \\
\text { well balanced break fast. } \\
\text { UK-The product focus on } \\
\text { healthy and slim life. }\end{array}$ & $\begin{array}{l}\text { The product having special } \\
\text { protein and fibre with } \\
\text { delicious flavour makes one } \\
\text { feel full for a long time and also } \\
\text { gives slim and healthy look. }\end{array}$ & $\begin{array}{l}\text { It shows to feel the special } \\
\text { one need to eat special. The } \\
\text { product having more cherries } \\
\text { raspberries and strawberries } \\
\text { gives a healthy slim look. }\end{array}$ \\
\hline 39 & $\begin{array}{l}\text { Kellogg'sChocos } \\
\text { India-The product focus on } \\
\text { power of milk with chocolate } \\
\text { flavour. }\end{array}$ & $\begin{array}{l}\text { The product is so tasty that a } \\
\text { little boy sacrifices watching } \\
\text { the T.V and others thing and } \\
\text { study as his mother says gives }\end{array}$ & $\begin{array}{l}\text { It shows two siblings } \\
\text { desirous of having the } \\
\text { product with chocolate milk } \\
\text { shake with crunchy pops, }\end{array}$ \\
\hline
\end{tabular}




\begin{tabular}{|c|c|c|c|}
\hline & $\begin{array}{l}\text { Australia- Healthy chocos } \\
\text { with taste like chocolate milk } \\
\text { shakes. }\end{array}$ & it everytime for studying. & $\begin{array}{l}\text { rush to purchase milk from } \\
\text { shop and on return, they see } \\
\text { their father already eating it } \\
\text { and after that they share it } \\
\text { together. }\end{array}$ \\
\hline 40 & $\begin{array}{l}\text { Yakut } \\
\text { India- The product focus on } \\
\text { good bacteria to increase } \\
\text { intestine strength. } \\
\text { UK- The product contains } \\
\text { goodness }\end{array}$ & $\begin{array}{l}\text { A yoga instructor after } \\
\text { completing her class, drinks } \\
\text { the product to kill all bad } \\
\text { bacteria making the body } \\
\text { seventy percent stronger. }\end{array}$ & $\begin{array}{l}\text { The product is shown as } \\
\text { enriched with vitamin } D \text { and } \\
\text { E and is aimed for perfect } \\
\text { health. }\end{array}$ \\
\hline 41 & $\begin{array}{l}\text { RedBull } \\
\text { India- The product focus on } \\
\text { the power of the imagination. } \\
\text { USA-The product gives wings } \\
\text { to imagination. }\end{array}$ & $\begin{array}{l}\text { It shows during car race the } \\
\text { driver and his partner have the } \\
\text { product and after that they } \\
\text { starts flying with the car } \\
\text { through the mountain as the } \\
\text { product gives wings. }\end{array}$ & $\begin{array}{l}\text { The product simply gives } \\
\text { wings for imagination as } \\
\text { termite transform a simple } \\
\text { wooden table into a beautiful } \\
\text { design table. }\end{array}$ \\
\hline 42 & $\begin{array}{l}\text { Pedigree } \\
\text { India- The product focus on } \\
\text { perinial hope } \\
\text { UK-The product focus on } \\
\text { healthy nutrition food for } \\
\text { dogs. }\end{array}$ & $\begin{array}{l}\text { A kid throws his shoe at home } \\
\text { as he had lost a football match } \\
\text { but his little dog brings the } \\
\text { shoe back again and thus } \\
\text { taught the kid not to loose } \\
\text { hope. Similarly, Pedigree with } \\
\text { nutrients helps to develop } \\
\text { confidence to fight back. }\end{array}$ & $\begin{array}{l}\text { It shows the new product } \\
\text { pouches has all the needs for } \\
\text { the pet dogs and they enjoy } \\
\text { it. The product being good } \\
\text { food for pets help them grow } \\
\text { faster. }\end{array}$ \\
\hline 43 & $\begin{array}{l}\text { Whiskas } \\
\text { India-The product focus on } \\
\text { delicious fresh meal for } \\
\text { kitten. } \\
\text { UK- The product shows its } \\
\text { best to increase the curiosity. }\end{array}$ & $\begin{array}{l}\text { A couple bring the little kitten } \\
\text { to their home and feed the } \\
\text { product for faster growth and } \\
\text { healthy life. }\end{array}$ & $\begin{array}{l}\text { It shows a kitten curiosity } \\
\text { looking at the window as the } \\
\text { rain falling and then the } \\
\text { product is given to the kitten } \\
\text { which she enjoys. }\end{array}$ \\
\hline 44 & $\begin{array}{l}\text { Ariel } \\
\text { India-The product focus on } \\
\text { removal of stains even by a } \\
\text { man. } \\
\text { UK-The product focus on } \\
\text { cleanliness of sensitive } \\
\text { clothes. }\end{array}$ & $\begin{array}{l}\text { It shows a single dad taking up } \\
\text { the responsibility of a girl child } \\
\text { very sincerly. Even when the } \\
\text { child pores sauce in her dress } \\
\text { then he use the product easily } \\
\text { for removing the toughest } \\
\text { stains in single wash. }\end{array}$ & $\begin{array}{l}\text { It shows a boy and a girl } \\
\text { come home with tough stains } \\
\text { on clothes which can not be } \\
\text { washed in hot water. The } \\
\text { mother uses the product as it } \\
\text { works lower temperature } \\
\text { water and remove all stains. }\end{array}$ \\
\hline 45 & $\begin{array}{l}\text { Tide } \\
\text { India- The product removes } \\
\text { toughest stains in a wash. } \\
\text { USA- The product focus on } \\
\text { quality for years. }\end{array}$ & $\begin{array}{l}\text { The product cleans dirty } \\
\text { uniform of a child, who plays } \\
\text { with mud regularly, in a single } \\
\text { wash thereby removing all } \\
\text { worries of his mother. }\end{array}$ & $\begin{array}{l}\text { The product for the last } \\
\text { seventy years with its super } \\
\text { quality performance for } \\
\text { cleaning the toughest dirt it is } \\
\text { holding the pioneer position } \\
\text { in American market. }\end{array}$ \\
\hline 46 & $\begin{array}{l}\text { Huggies } \\
\text { India-The product focus on } \\
\text { soft touch like mothers. } \\
\text { USA-The product focus on } \\
\text { natural care for babies. }\end{array}$ & $\begin{array}{l}\text { The product with soft feelings } \\
\text { like pure cotton and advanced } \\
\text { dry touch sheet makes it as } \\
\text { comfortable as mother's hugs. }\end{array}$ & $\begin{array}{l}\text { The product is the softest } \\
\text { diaper with trusted } \\
\text { protection of plant based } \\
\text { materials and free of } \\
\text { parabens or other harsh } \\
\text { ingredients. }\end{array}$ \\
\hline 47 & $\begin{array}{l}\text { Pampers } \\
\text { India-The product focus on } \\
\text { dryness for entire night. } \\
\text { UK-The product focus on } \\
\text { convinience like pants } \\
\text { (underwear). }\end{array}$ & $\begin{array}{l}\text { A doctor is shown } \\
\text { recommending the product to } \\
\text { a mother as the product has } \\
\text { the ability to transfer the urine } \\
\text { into gel and stops chances of } \\
\text { infection and catching cold. }\end{array}$ & $\begin{array}{l}\text { This product is very easy to } \\
\text { put on as its just like a pants } \\
\text { which keeps dryness upto } \\
\text { twelve hours. }\end{array}$ \\
\hline
\end{tabular}




\begin{tabular}{|c|l|l|l|}
\hline 48 & $\begin{array}{l}\text { Johnson`s (shampoo) } \\
\text { India-This product focus on } \\
\text { the trust. } \\
\text { UK-The product focus on } \\
\text { safety for eyes during bath. }\end{array}$ & $\begin{array}{l}\text { The product does not have } \\
\text { formaldehyde, parabens and } \\
\text { harmful chemicals provides } \\
\text { hundred percent gentle care of } \\
\text { the babies hair. }\end{array}$ & $\begin{array}{l}\text { The product is the first baby } \\
\text { shampoo special formulated } \\
\text { with unique no more tears } \\
\text { formula proven to be as } \\
\text { gentle to eyes as pure water. }\end{array}$ \\
\hline 49 & $\begin{array}{l}\text { Johnson`s (Baby Bed time } \\
\text { Bath) } \\
\text { India-The product focus on } \\
\text { comfort of baby in bed. } \\
\text { USA-The product focus on } \\
\text { disturbance free sleep for } \\
\text { babies. }\end{array}$ & $\begin{array}{l}\text { It it is clinically proven that } \\
\text { before bed if the baby take } \\
\text { bath with the product, it would } \\
\text { help the baby fall asleep easier. }\end{array}$ & $\begin{array}{l}\text { It shows that the product } \\
\text { clinically proven to help a } \\
\text { baby to sleep faster and help } \\
\text { lotion with natural calm } \\
\text { aromas are also suggested by } \\
\text { termatologist }\end{array}$ \\
\hline
\end{tabular}

\section{ANALYSIS OF THE RESUlTS}

Soft Drinks and Beverages: In this study the advertisement of Coca-cola, 7up, Pepsi, MountainDew, Sprite, Tropicana has been analyzed for both in India and the West. Most of the Indian advertisements of Soft drinks and Beverages mainly focus on young generation, couple, youth, college students and friend zone to promote their products. Indian ads showed break time at $3 \mathrm{o}^{\prime}$ clock is enjoyed by young girls with Coca-cola; Fido Dido of 7up gives better idea to rescue couples from neighborhood uncle; young boy of college student union breaks the hunger strike as he couldn't resist himself from Pepsi, the gangster took the adventure steps with Mountain-Dew; One gulp of Sprite refresh the boy in summer and Tropicana with Iron and Vitamin makes young lady strong. Advertisements of USA influence overall population at a wider range. Girl cheers with Coca-cola with her big gang; 7up invented vending machine to win customer's preferences; no generation gap of consuming Pepsi; Mountain-Dew shows if there is a will there is a way; Sprite refreshed players along with audiences; Tropicana shows core feature of fruity and juicy with pro-biotic formula.

Noodles:Maggi and Top Ramen has been taken for this study. Indian advertisements are displayed by categorizing the emotional space of mother's love for her children whereas Western advertisement shows the reason behind choosing smartly these products. Maggi gives instant relief to a mother of an independent daughter as she(daughter) learned the quick easy recipe of Maggi just like her mother. Again Top Ramen shows that mother brings back the happiness to her sons by cooking Top Ramen, the instant noodle which has the same great taste. The Western advertisement of Maggi shows the several reasons behind choosing it for its taste and fiber, healthy as it has iron and sunflower seeds oil, instant relief from hunger, pleasure in winter and convenient solution of family meal. Top ramen focus mainly on the taste of salt that can be enjoyed by those whose favorite flavor is salt.

Tea:Both the Indian and Western advertisement of Nescafe conveys a strong message in an emotional way. Indian advertisement shows success comes with strong mind just like the strong bonding of father and son whereas Western advertisement conveys the message for those moments that always matter when close persons always stand by side though out the success. Tetley in Indian advertisement is seen as a substitute of healthy food that make people active from inside, whereas Tetley in Western advertisement shows the togetherness that makes anyone to talk. Lipton also shows as the healthy green tea that is necessary along with exercise in Indian advertisement whereas Lipton tea in Western advertisement shows the process of growing tea leaves in all natural way that gives the freshness.

Toothpaste: In Indian advertisement Colgate focuses the emotional attachment with consumer as the tagline of the advertisement states the great things can be started with a smile; rest of the toothpaste focuses mainly on the core feature of the product, such as Oral-B gives eight benefits in one toothpaste promoted by Bollywood stars and Sensodyne shares the review of one of its clients that shows the relief from sensitivity and helps to restore natural whiteness. Whereas Western advertisement of Colgate shows its anti-bacterial protection for healthier mouth; Oral-B in two variants of toothpaste and mouthwash and lastly the dentist review of repairmen of sensitive teeth with Sensodyne.

Shampoo: The famous Bollywood star's recommendation for L'Oreal Paris Total Repair 5 that won over damaged hair is the main focus to promote the product. Pantene focuses on advanced feature that gives freedom to open hair. Head and Shoulders only focus on removing dandruff. Dove in Indian advertisement showed the unbeatable damage repair of hair, and hair can be wore in own way. 
Again Bollywood star in Indian advertisement promoted the TRESme pro-collection that gives salon like hair at home with Keratin and Argan Oil treatment, whereas TRESme Botanic in Western advertisement nourishes and replenishes hair with professional touch. L'Oreal shampoo focuses on gentle wash to colored hair; Pantene focuses on advanced feature to strengthen the hair and make it more beautiful. Head and Shoulders not only focus to dandruff free hair but also give $100 \%$ flake free nourished hair. Dove Nutritive Solution in Western advertisements has proven a clear difference by treating roses with Dove that repairs $90 \%$ of daily hair damage.

Soap: Indian ads of Dove soap focus to convert non user to a regular user by initiating 7 days test and putting forward the differences after using Dove soap, whereas Western ads shows the user loyalty as Dove can make skin soft, clean and moisturized and build up the confidence of every working women. Dettol teaches Indian kids to be germ free all the time by using hand washes in home and sanitizer outside. In Western ads show anti-bacterial Dettol gives 99.9\% protection from germs than other ordinary hand wash and also launched automatic Dettol no touch kit. The advertisement induced kids to feature the product.

Body care: By modifying existing product with different variations Nivea introduced the Aloe Hydration Body Lotion for healthy looking skin in summer which is promoted by an actress. Vaseline focuses with advanced healing power that can moisturize the dry skin especially in winter. In Western ads its is seen Nivea came up with unique formula of Almonds Oil that moisturizes skin all day long, it also focused on Restoring Micro droplets of Vaseline jelly to moisturize dry skin. Indian and Western both focused on Men segment for the Pond's Men Face wash. Indian ads show recharging the energy of dull skin whereas Western ads show long lasting Oil Control in Pond's Men Face washes.

Health Drinks: Health drinks mainly focused to kids, children, adolescent boys and girls those are interested in every new sphere of life in both Indian and Western Ads. Indian Ads showed Horlicks make kids more tall, strong and sharp to increase their skills in everywhere like dance, sport also in education. Pediasure focused small playschool kids to gain better immunity and visible growth in season change with 37 vital nutrients. Milo focused on adolescent boys and girls to give energy for playing sports with milk, malt, vitamins and calcium. Boost focuses youths and young boys in sports to provide 3 times more stamina. Western ads showed Horlicks for wholesome goodness of family starting from kids to adult. Pediasure helps kids to gain weight just in 8 weeks. Milo shows that mother recommends Milo to her children for more calcium, more iron and more vitamin D. A lady photographer promotes Boosts as a Nutritional Drinks to be happy and healthy with more protein, vitamin and minerals.

Chocolate- Both the Indian and Western advertisement of Dairy milk conveys sensitive feelingsof life. Indian advertisement shows hidden love between two brothers and they celebrate their love with sweets, where as Western advertisement conveys the message for love of mother and daughter. Kitkat in Indian advertisement shows independent woman express her feeling with happiness where as in Western ads shows happiness is follow in every situation. Oreo shows crunchy surprise in every situation in Indian advertisement where as in Western advertisement shows true bonding between different types of people. Snickers in Indian ads shows hunger of a person change his personality and in Western ads shows hunger can stop important jobs also.

Snacks- In this study the advertisement of Doritos and Lays has been analyzed for both in India and the West. Indian advertisement in Doritos shows a new taste of chips in the market where as Western advertisement shows the boldness after having the product. Lays chips in Indian advertisement shows a variety of flavours with various moods and emotions, and in Western ads spreads smile with happiness in every situation.

Body Spray- In Indian advertisement of Rexona protects every woman by ten times odour protection and saves skin from bacteria caused by sweat, whereas in Western ads shows three times stronger protection from sweat and body odour. In Indian ads Axe body spray for men may be needed in any moment and in Western ads it shows that one doesn't need to have good physique, needs only grooming.

Cornflakes- In Indian advertisement Kellogg`s plain displayed emotional father's love for his daughter whereas Western advertisement shows healthy and wealthy family relationship. Kellogg's Special K in Indian advertisement is seen as a substitute for healthy food, whereas Western ads shows healthy and slim lifestyle. Kellogg's Chocos in Indian advertisement shows that mothers give Chocos every time for studying whereas, in Western ads shows two siblings have true friendship by sharing the product.

Health Supplement-Yakut and Red Bull has been taken for this study. Yakut in Indian ads shows that to kill the bad bacteria a yoga instructor takes this everyday whereas in Western ads shows all vitamins enrich the product. Red Bull in Indian ads shows the 
power of imagination, where as in Western ads gives wings to imagination.

Animals Food- Whiskas and Pedigree has been taken for this study. Whiskas is mainly used for kitten and Pedigree is used for dogs. Whiskas in Indian ads shows the wet and dry food support daily life style of kitten and in Western ads it focuses on health of a kitten. Pedigree in Indian ads shows a friendly relationship between a kid and a dog, where as in Western ads showevery dog enjoy this food.

Washing Powder- Ariel in Indian advertisement shows a single dad takes responsibility of a girl child and he enjoys it even when the child gets dirt in her dress, where as in Western ads shows a boy and a girl come home with tough stains on clothes and their mother washes their clothes with care. Tide in Indian ads show how to clean a dirty uniform with gentle care, whereas in Western ads show the quality of years.

Diapers- Huggies and Pampers have been taken for this study. Huggies in Indian ads shows a baby enjoying soft feelings, whereas in Western ads show natural care of every baby. Pampers in Indian ads shows a doctor recommending the product as safe for babies, especially new born babies, and in Western ads shows easiness to put on while maintaining dryness upto twelve hours.

Baby Products- Johnson`s shampoo and Johnson`s baby bed time bath has been taken in this study. In Indian advertisement Johnson's baby shampoo shows gentle care for babies, whereas in Western advertisement shows baby shampoo made in special formulation with unique no more tears formula. Johnson`s baby bed time bath in Indian ads shows bath before bed gives sound sleep, whereas in Western ads shows no disturbance when a baby sleep faster and longer.

\section{CONCLUDING REMARKS}

Advertisementsare intended to attractconsumer's attention, create awareness of the product and stimulate final sales. On analysis of advertisements of 49 FMCG products displayed through audio-visual media in India and the West, it is clearly found that the contents, visuals and messages are planned and designed to cater socio cultural demands of target population. The advertisements emphasize on core product features in both places in general but there are subtle differences in content of messages. Indian advertisements focus more on family bonding, love and affection, instant gratification, social approval and personal benefits. Western advertisements focus on social bonding, social status, delayed gratification, self approval and environmental benefits. It is also found that the makers have modified the contents, visuals and process of delivery according to the cultural maturity of their target audiences. In conclusion, it can be stated that customization of advertisement to suit the tastes, preferences and mental state of audiences are followed by advertisers of the same FMCG products both in India and Western countries.

\section{WEBSITES CONSULTED FOR ADVERTISEMENTS}

1 https://youtu.be/8mKFF5K4aU

2 https://youtu.be/5-ahnFYzMp8

3 https://youtu.be/hrPQfZSeC-Q

4 https://youtu.be/nkgQFOOr7ug

5 https://youtu.be/CqYzIAE2LG8

6 https://youtu.be/OgHYd67OumQ

7 https://youtu.be/819Ftn5CG24

8 https://youtu.be/Enew6dk8pQ4

9 https://youtu.be/ZOwOM-N1Trc

10 https://youtu.be/JeFAx2fJnfO

11 https://youtu.be/xPaylywKN78

12 https://www.adsoftheworld.com/media/film/tropic ana_feel_like_a_billion

13 https://youtu.be/DyMtcblMXfM

14 https://youtu.be/XrOAj3cPQqQ

15 https://youtu.be/t8XVHEN2VXA

16 https://youtu.be/Vx58QGbdzHO

17 https://youtu.be/T6rqWYcalcU

18 https://youtu.be/jZtEXMBbaZg

19 https://youtu.be/GnyxdOfU7_w

20 https://youtu.be/PE8gVb6DrAw

21 https://youtu.be/GbqZTlY3ppU

22 https://youtu.be/c0WD6ivxDdI

23 https://youtu.be/VCmOmrCPbyk

24 https://youtu.be/VAJDw1shmOU

25 https://youtu.be/gix4fVeO16U

26 https://youtu.be/lt0t82dmT2M

27 https://youtu.be/ibc-3pzlejQ

28 https://youtu.be/eulJBtIlcWw

29 https://youtu.be/Z_J7Zeqye_k

30 https://youtu.be/c4s9-_XiIPc

31 https://youtu.be/HRuKXjFiR1Y

32 https://youtu.be/NCKqn_Aq5ik

33 https://youtu.be/NTFONinqQpA

34 https://youtu.be/1DNhMmzDc_c

35 https://youtu.be/8t9Ksd2nFiU

36 https://youtu.be/CLWezOaBfvc

37 https://youtu.be/90KsVQfMeiM

38 https://youtu.be/6qP0M_h9phs

39 https://youtu.be/gU_26k6-hyO

40 https://www.ispot.tv/ad/I8xz/dove-beauty-barironworker

41 https://youtu.be/CPcn9k7a1PU

42 https://youtu.be/7CXwUUB-cAY

43 https://youtu.be/MdT4IaLZbXY

44 https://youtu.be/9mBv6VRuB1k

45 https://youtu.be/Vbj99FpanEs

46 https://youtu.be/6ncXNwGH4Yk

47 https://youtu.be/6IQmr7k2rMA

48 https://youtu.be/81qigTHO4Cw

49 https://youtu.be/Q9Sm8xdigco

50 https://youtu.be/OMxeldmKLC4

51 https://youtu.be/sjxQrHme-y4 
52 https://youtu.be/Pqbhc1OLYSs

53 https://youtu.be/RmoXTMCZ1xo

54 https://youtu.be/WQ_eQmvECyw

55 https://youtu.be/VLNOzsd4mgQ

56 https://youtu.be/T1GgbxIRJOo

57 https://youtu.be/k80dLDdzkdY

58 https://youtu.be/lOeEqeizNCA

59 https://youtu.be/5HrCt34fyG4

60 https://youtu.be/OzTkOhrBy6E

61 https://youtu.be/CjQJ_lYdsdo

62 https://youtu.be/wOUHBs3bR8o

63 https://youtu.be/n3wBSrlcEBO

64 https://youtu.be/NIInvY8XDHO

65 https://youtu.be/tbGhJBZwKYE

66 https://youtu.be/Qh_gOK6xDNA

67 https://youtu.be/gjbMDHdQfw8

68 https://youtu.be/1G7BFVCZrAU

69 https://youtu.be/yVmFNUnEHbO

70 https://youtu.be/KlxooVR31VM

71 https://youtu.be/FpTGiaoh-CI

72 https://youtu.be/aVxYSeZp8Z4

73 https://youtu.be/h5Avd0b9Mgo

74 https://youtu.be/DpyDa2FXAuU

75 https://youtu.bel_MgVOAEL2q4

76 https://youtu.be/TZNO8fj9AvY

77 https://youtu.be/PTD6qaBQcyo

78 https://youtu.be/XOEMYTFerMM

79 https://youtu.be/sFBmnS2n7n4

80 https://youtu.be/IxYd6Ky0oTM

81 https://www.redbull.com/in-en/videos/rally-in

82 https://youtu.be/WLyGLk2hDw4

83 https://youtu.be/zCPY_LsXDDo

84 https://youtu.be/-6FJRVnnlqk

85 https://youtu.be/85sn4a6AGTk

86 https://youtu.be/ZyQrdJ5iiAY

87 https://youtu.be/g8eHEB-KET4

88 https:/lyoutu.be/cU8_SHxTFO

89 https://youtu.be/oxsHp196_Nk

90 https://youtu.be/LReIPWUe3BY

91 https://youtu.be/KlI6FaJtMEM

92 https://youtu.be/za4841RvKYO

93 https://youtu.be/5G3HKD03XzE

94 https://youtu.be/u6yNuBTAtTI

95 https://youtu.be/bdXvZNdNCiO

96 https://youtu.be/CUMcTEeJ-s4

97 https://youtu.be/cZ57djJQ_3k

98 https://youtu.be/_BlxggtKoaw 